\title{
PROPOSING AN INTEGRATIVE-PROGRESSIVE MODEL IN HANDLING TROUBLED INDONESIAN OVERSEAS WORKERS IN THE TRANSIT AREA \\ (A SOCIO-LEGAL RESEARCH IN TANJUNG PINANG CITY, KEPULAUAN RIAU PROVINCE)*
}

\author{
Rina Shahriyani Shahrullah $^{* *}$ and Elza Syarief ${ }^{* * *}$
}

\footnotetext{
* This paper is part of research funded by the Directorate General of Higher Education of Indonesia (DIKTI) under Hibah Bersaing Grant 2015-2016.

** Head of Postgraduate Study of Law, Universitas Internasional Batam, Indonesia.

*** Senior Lecturer of Postgraduate Study of Law, Universitas Internasional Batam, Indonesia.
}

\section{Article Info}

Received : 19 October 2015 | Received in revised form : 30 November 2015 | Accepted : 12 December 2015 Corresponding author's e-mail : rina@uib.ac.id/elzasyarief@elzalaw.co.id.

\begin{abstract}
Tanjung Pinang City is a transit area for troubled Indonesian overseas workers from Singapore and Malaysia. Previous research revealed that citizens of Tanjung Pinang City criticized the treatments given by the local government to the deported workers by reason that they were not the citizens of the Riau Islands Province, yet the local government has to provide shelters and funds prior to returning them to their home towns. The treatments for the deported workers in the transit area have also raised pros and cons among the stakeholders who are in charge of handling the deported workers. This circumstance may not occur if a special regional regulation of the Riau Islands Province has been issued to govern the troubled Indonesian overseas workers in the transit area. Due to this vacuum of law, this research aims to establish a mechanism in handling the deported workers in the transit area by designing an integrative-progressive model which can be adopted by the stakeholders. The model is to link the legal and non-legal issues and as well as to provide the collaborative mechanisms for the stakeholders based on the approaches of the integrative and progressive legal theory.
\end{abstract}

Keywords: integrative-progressive model, troubled indonesian overseas workers, Tanjung Pinang, Indonesia

\begin{abstract}
Abstrak
Kota Tanjung Pinang merupakan salah satu daerah transit bagi Tenaga Kerja Indonesia Bermasalah/TKIB yang dideportasi dari Malaysia dan Singapura. Pada penelitian sebelumnya menyatakan bahwa penduduk Tanjung Pinang mengkritisi layanan yang diberikan pemerintah kota kepada warga deportasi pada dasarnya bukan warga Provinsi Kepulauan Riau. Pro dan kontra pendapat mengenai kebijakan Pemerintah dalam menangani TKIB termasuk penyediakan rumah penampungan dan pendanaan untuk memulangkan mereka ke kampung halamannya. Hal ini tidak akan terjadi seandainya Pemerintah Kepulauan Riau menerbit Perda terkait penanganan TKIB di daerah transit. Sehubungan dengan kekosongan hukum tersebut, penelitian ini bertujuan merumuskan mekanisme penanganan TKIB di daerah transit dengan merancang model intergratif-progersif yang dapat diadopsi oleh pihak terkait. Model tersebut menghubungkan persoalan hukum dan non hukum serta mekanisme kolaborasi bagi pihak terkait berdasarkan pendekatan teori hukum intergratif dan progresif.
\end{abstract}

Kata Kunci: model integrative-progressive model, Tenaga Kerja Indonesia Bermasalah, Tanjung Pinang, Indonesia 


\section{Introduction}

Indonesia is one of the ASEAN countries which send many of its human resources to work overseas. Based on the data of the National Authority for the Placement and Protection of Indonesian Overseas Workers (hereinafter refer to as BNP2TKI), most of Indonesian overseas workers (Tenaga Kerja Indonesia/TKI) work in the following countries.

Table 1: The Most Popular Destination Countries for Indonesian Overseas Workers ( 1 January - 31 October 2014)

\begin{tabular}{clr}
\hline No. & \multicolumn{1}{c}{ Destination Countries } & Total Number \\
\hline 1 & Malaysia & 107,085 \\
\hline 2 & Taiwan & 68,874 \\
\hline 3 & Saudi Arabia & 38,104 \\
\hline 4 & Hongkong & 30,208 \\
\hline 5 & Singapore & 25,601 \\
\hline 6 & United Arab Emirates & 15,276 \\
\hline 7 & Oman & 15,035 \\
\hline 8 & South Korea & 9,623 \\
\hline 9 & Brunei Darussalam & 9,298 \\
\hline 10 & United States of America & 7,839 \\
\hline
\end{tabular}

Source: BNP2TKI, 2015.

The BNP2TKI reported that number of returning Indonesian overseas workers have fluctuated as it is shown by the data below.

Table 2: Returning Indonesian Overseas Workers (2006-2014)

\begin{tabular}{|c|c|c|c|}
\hline Year & $\begin{array}{l}\text { No. Returning } \\
\text { Workers }\end{array}$ & $\begin{array}{l}\text { Troubled Overseas } \\
\text { Workers }\end{array}$ & $\begin{array}{l}\text { Percentage of Troubled } \\
\text { Overseas Workers }\end{array}$ \\
\hline 2006 & 376,782 & 57,971 & $15.4 \%$ \\
\hline 2007 & 354,921 & 58,085 & $16.4 \%$ \\
\hline 2008 & 447,016 & 50,765 & $11.4 \%$ \\
\hline 2009 & 492,073 & 53,168 & $10.8 \%$ \\
\hline 2010 & 539,169 & 95,060 & $14.4 \%$ \\
\hline 2011 & 494,266 & 72,194 & $14.7 \%$ \\
\hline 2012 & 393,720 & 47,620 & $12.9 \%$ \\
\hline 2013 & 260,093 & 44,087 & $13.6 \%$ \\
\hline 2014 & 201,779 & 30,661 & $15.1 \%$ \\
\hline
\end{tabular}

Source: BNP2TKI, 2015. 
The Protection Bureau of Indonesian Citizens (Dit. Perlindungan WNI dan BHI) stated that Indonesian overseas workers are deported based on several reasons, namely unpaid salary (45.50\%), unsuitable employer (16.26\%), sickness $(11.42 \%)$ over workload (10.01\%), abuse/physical violence $(9.93 \%)$, sexual harassment (3.99\%), uncomfortable (2.35\%), and unsuitable working hours (0.16\%). Among the returning Indonesian overseas workers, the BNP2TKI reported that more that $10 \%$ of Indonesian overseas workers who have deported to Indonesia are classified as "Troubled Overseas Workers" (hereinafter refer to as Tenaga Kerja Indonesia Bermasalah/TKIB).

The term "Troubled Overseas Workers" is used interchangeably with the term "Problematic Overseas Workers" since this term is translated from the Indonesian term of "Tenaga Kerja Indonesia Bermasalah (TKIB)". "TKIB are deported to Indonesia because they encounter problems related to their documents such as the expiration of visas, passports and other related documents" ${ }^{11}$. Most of TKIB are deported from Malaysia and Singapore via Tanjung Pinang City, the capital of the Riau Islands Province (Provinsi Kepulauan Riau) because it is closed to Singapore and Malaysia.

Due to the proximity of Tanjung Pinang City, the City is used as a transit area for the embarkation and the debarkation of Indonesia migrant workers to and from Malaysia and Singapore. ${ }^{2}$

Data on Table 3 shows that among places of debarkation in Indonsia, Tanjung Pinang City is the destination place for most of TKIB. The process of handling TKIB is regulated by the Presidential Decree of Indonesia No.106 of 2004 on the Establishment of Coordinating Team for Returning Indonesian Troubled Overseas Workers (TKIB) and their families from Malaysia which was replaced by Presidential Regulation No.45 of 2013 regarding the Coordination of Returning Indonesian Workers. All expenses arises from the process of handling TKIB are borne by the Indonesian Central Government under the national budget (Anggaran Pendapatan dan Belanja Negara/APBN). However, based on the preliminary research, it was found that not all expenses are covered by the APBN. Unexpected expenses such as the hospital expenses when a TKIB delivers a baby or passes away are not covered by the APBN. The Tanjung Pinang City Budget (Anggaran Pendapatan Belanja Daerah/APBD) does not cover such expenses because there is no regional regulation of the Riau Islands Province specifically issued to govern the troubled Indonesian overseas workers in the transit area such as Tanjung Pinang City. In the absence of this particular regulation, this research aims to establish a mechanism in handling the deported workers in the transit area by designing an integrative-progressive model which can be adopted by the stakeholders. The model is to link the legal and non- legal issues and as well as to provide the collaborative mechanisms for the stakeholders based on the approaches of the integrative and progressive legal theory.

${ }^{1}$ Rina Shahriyani Shahrullah (1), “'The Missing Link' Dalam Perlindungan Tenaga Kerja Indonesia Bermasalah (TKIB) Di Daerah Transit (Studi Lapangan Pada TKIB Di Kota Batam)," Jurnal IPTEKS Terapan Volume 4 No.3 (December 2010): 3.

${ }^{2}$ Jaleswari Pramodharwardani, Perlindungan Hukum Terhadap Pengiriman Buruh Migran Perempuan Indonesia Ke Malaysia (Jakarta: LIPI Press, 2007); Benhard Nababan, Permasalahan Buruh Migran Selama Tahun 2007 (Jakarta: Migrant Care, 2007); International Migrant Workers Union (IMWU), Permasalahan Buruh Migran Indonesia Di Negara-Negara Non ASEAN (2006); M. Hasballah Saad, Panduan Buruh Migran (Tenaga Kerja Indonesia/TKI) di Taiwan (Jakarta: Komnas HAM, 2005). 
The data below shows the returning Indonesian overseas workers including TKIB.

Table 3: Debarkation of Indonesian Overseas Workers ( January - 30 September 2014)

\begin{tabular}{llrr}
\hline No. & \multicolumn{1}{c}{ Place of Debarkation } & \multicolumn{1}{c}{$\begin{array}{c}\text { Returning } \\
\text { Indonesian } \\
\text { Overseas Workers }\end{array}$} & $\begin{array}{c}\text { Troubled } \\
\text { Indonesian } \\
\text { Overseas } \\
\text { Workers }\end{array}$ \\
\hline 1 & BPK TKI Selapajang Tangerang & 24.104 & 8.727 \\
\hline 2 & Soekarno Hatta (Terminal 2) & 38.105 & 0 \\
\hline 3 & Juanda Surabaya & 42.914 & 1.778 \\
\hline 4 & Ahmad Yani Semarang & 22.262 & 238 \\
\hline 5 & Tanjung Pinang & 13.082 & 13.082 \\
\hline 6 & Lombok Mataram & 7.138 & 4 \\
\hline 7 & Adi Soetjipto Yogyakarta & 5.605 & 116 \\
\hline 8 & Adi Soemarmo Solo & 7.466 & 1.830 \\
\hline 9 & Entikong & 2.420 & 1.647 \\
\hline 10 & Nunukan & 1.647 & 2 \\
\hline 11 & Sultan Mahmud Badaruddin II & 1.280 & 28 \\
\hline 12 & Palembang & 372 & 49 \\
\hline 13 & Kusein Sastranegara Bandung & 1.218 & 27.528 \\
\hline & TOTAL & 167.613 &
\end{tabular}

Source: BNP2TKI, 2015.

\section{Legal and Theoretical Framework}

\section{A. Legal Instruments relating Indonesian Overseas Workers}

The 1945 Constitution (UUD 1945) under Article 27 (2) stipulates that "Every citizen has the right to employment and decent living for humanity". Article 28D (2) of the 1945 Constitution states that "Everyone has the right to work and obtain remuneration and treatment fair and reasonable in relation employment". In addition, Article 31 of the 1945 Constitution emphasizes that "Every worker has the same rights and opportunities to choose, get or change jobs and earn a decent income in inside or outside the country". As the manifestation of the 1945 Constitution, the Indonesia Government passed Law No. 39 of 2004 concerning the Placement and Protection of Indonesian Workers Overseas. This Law is the main statutory instrument related to social and legal protection for Indonesian overseas workers. This Law sets out legal provisions pertaining to the placement procedures, such as pre- placement training, pre-departure program, health examinations, workers protection, dispute settlements, supervision of placement and protection activities for Indonesia overseas migrant workers.

In addition, the Indonesian Government issued the Government Regulation No.4 
of 2013 regarding the Methods of the Placement of Indonesian Overseas Workers by the Government (Peraturan Pemerintah Nomor. 4 Tahun 2013 Tentang Tata cara pelaksanaan Penempatan TKI di Luar Negeri oleh Pemerintah), the Government Regulation No.3 of 2013 on the Protection of Indonesian Overseas Workers (Peraturan Pemerintah Nomor. 3 Tahun 2013 Tentang Perlindungan Tenaga Kerja Indonesia di Luar Negeri), the Regulation of Manpower and Transmigration Ministry No. PER.14/MEN/X/2010 on the Implementation of the Placement and Protection of Indonesian Overseas Workers (Peraturan Menteri Tenaga Kerja dan Transmigrasi Republik Indonesia No. PER.14/MEN/X/2010 tentang Pelaksanaan Penempatan dan Perlindungan Tenaga Kerja Indonesia di Luar Negeri).

Prior to the Regulation of Manpower and Transmigration Ministry, the Indonesian President issued a Presidential Instruction No. 6 of 2006 (INPRES 2006) on Policy Reform on Placement and Protection System of Indonesian Overseas Workers. This INPRES regulates detailed actions to improve placement services of overseas workers, placement quality and to strengthen the function of Indonesian representatives in providing protection to Indonesian overseas workers. In 2006, a National Body for the Placement and Protection of Indonesian Overseas Workers (BNP2TKI) was established under the Presidential Regulation No. 81 of 2006 on the Establishment of National Body for the Placement and Protection of Indonesian Overseas Workers (BNP2TKI). "The Regulation aims to improve security, protection and empowerment of overseas workers". ${ }^{3}$ The Regulation was followed by the establishment of Overseas Cooperation Agency (BKLN) based on Regulation No. 28 of 2007. This regulation is derived from BNP2TKI. The Regulation focuses on the obligation of employment agencies to provide protection and pre-placement training for prospective Indonesian migrant workers.

Most of the laws and regulations above merely focus of the placement and protection of Indonesian overseas workers. The only legal instrument which can be relied by a transit area for TKIB is the Presidential Decree of Indonesia No.106 of 2004 on the Establishment of Coordinating Team for Returning Indonesian Troubled Overseas Workers (TKIB) and their families from Malaysia which was replaced by Presidential Regulation No.45 of 2013 regarding the Coordination of Returning Indonesian Workers. Yet, this Decree is not adequate to tackle all issues and problems faced by TKIB and stakeholders dealing with TKIB in the transit area.

\section{B. Theoretical Framework}

Yahya Muchyar stipulates that "legal theory" constitutes a branch of law which specifically focuses on various aspects of theoretical and practical from the specific positive law and interdisciplinary in its entirety. "Legal theory aims at acquiring knowledge and a better explanation, clearer, and more fundamentally concerned about the positive law".4 There are two functions of legal theory, namely:

a. Based on its theoretical function, legal theory is an instrument to analyze and assess legal studies which will be developed by jurists.

b. Based on its practical function, "legal theory is an instrument to analyze and

${ }^{3}$ Mahidol Migration Centre, Institute for Population and Social Research, Mahidol University, "Migrant Workers' Right to Social Protection in ASEAN: Case Study of Indonesia, Philippines, Singapore and Thailand (Data from BNP2TKI 1999)", http://www.ilo.org.

${ }^{4}$ Sudikno Mertokusumo, Teori Hukum (Yogyakarta: Universities Atma Jaya, 2011), p. 87. 
assess phenomenon which occurs and develop in society, nation, and state". ${ }^{5}$

This research utilizes three legal theories to approach the issues of TKIB and establish a model which can link legal and non- legal issues of TKIB. The first theory adopted by this research is "Responsive Legal Theory" by Nonet-Selznick. According to this theory, "social changes and social justice need a responsive legal approach" ${ }^{6}$. Law should be a means to respond social needs and public aspiration. Law should use empirical approaches to respond social changes in order achieve justice and accommodate public aspiration. ${ }^{7}$ The second theory is "Progressive Legal Theory" by Satjipto Rahardjo. According to this theory, "law exists for the benefits of human, therefore if legal problems occur, the law should be reviewed and amended" ${ }^{8}$. Hence, human beings should not be forced to change for the sake of law. Law is not absolute and final, "law is always in the process and in the making because the ultimate purpose of law is the welfare and happiness of human". ${ }^{9}$ The third theory is "Integrative Legal Theory" by Romli Atmasasmita. This theory is based on the reconstruction of the approaches of "Law Development Theory by Mochtar Kusumaatmadja" and "Progressive Legal Theory by Satjipto Rahardjo". Law Development Theory by Mochtar Kusumaatmadja emphasizes that society is in the process of development; therefore law is a means in the process development which regulates the changes and developments of society. Law can be implemented if law is governed by a particular authority with a power to regulate. Yet, the power to regulate is also governed by law. "Integrative Legal Theory" attempts to mediate the approaches of Progressive Legal Theory and Law Development Theory by stating that "legal concepts (law) should be understood a system of norm, system of behavior and system of values which are part of certain society at certain time and place"10. "Integrative Legal Theory emphasizes that the law today (based on Law Development Theory) can be changed tomorrow because of society behaviours (based on Progressive Legal Theory)" 11, yet "the establishment of new law should be based on basic values and norms of Indonesian society which is integrated in the State Ideology (Pancasila)". ${ }^{12}$

\section{III.Research Methods}

\section{A. Research Design and Data Collection Techniques}

There are two types of legal research, namely normative legal research and sociolegal research. A Normative research method is also known as a doctrinal method. ${ }^{13}$ The normative research method is usually known as a study of documents, which using the secondary data as the sources, such as legal theories, regulations, court decisions and doctrines. ${ }^{14} \mathrm{~A}$ normative legal research is relevant to evaluate legal

\footnotetext{
${ }^{5}$ Salim HS, Perkembangan Teori dalam Ilmu Hukum (Jakarta: Raja Grafindo Persada, 2010), p. 18.

${ }^{6}$ Bernard L Tanya, Teori Hukum Strategi Tertib Manusia Lintas Ruang dan Generasi (Yogyakarta: Genta Publishing, 2010), p. 14.

7 Ibid.

${ }^{8}$ Satjipto Rahardjo, Membedah Hukum Progresif (Jakarta: Kompas, 2006), p. 9.

${ }_{9}$ Satjipto Raharjo, Hukum Progresif Urgensi dan Kritik (Jakarta: Penerbit Buku Kompas), pp. 34-37.

${ }^{10}$ Romli Atmasasmita (1), Teori Hukum Integratif: Rekonstruksi Terhadap Teori Hukum Pembangunan dan Teori Hukum Progresif (Yogyakarta: Genta Publishing, 2012).

11 Ibid.

12 Romli Atmasasmita (2), "Mengurai Sepintas Hukum integratif," http://www.negarahukum.com / hokum/mengurai-sepintas- \%E2\%80\%9Chukum-integratif\%E2\%80\%9D-romli-atmasasmita.html.

${ }^{13}$ Amiruddin, Pengantar Metode Penelitian Hukum (Jakarta: Raja Grafindo Press, 2004), p. 118.

${ }^{14}$ Topo Santoso, "Penulisan Proposal Penelitian Hukum Normatif," (Deliverd in Legal Research Course
} 
doctrines, theories, principles, or substances of positive legal orders; therefore it is frequently referred to as 'law in books'. In this regard, this type of research adopts 'statute, case, comparative and conceptual approaches'. ${ }^{15}$ Different from the normative legal research, a socio-legal research considers law as a social phenomenon with a structural approach. ${ }^{16}$ This type of research is relevant to evaluate the relationship between law and society in order to ascertain the effectiveness and implementation of law in the society; therefore it is commonly referred to as 'law in action.' ${ }^{17}$ This research adopts a socio-legal research method to understand law as a social phenomenon. Based on the approach of a socio-legal research, the problems of TKIB in the transit area are regarded as social phenomenon as they occur in the society and require the involvement of various stakeholders including public participation to handle the problems. Laws and policies which deal with TKIB problems are the integrated parts of this social phenomenon because the laws and policies constitute the basic references for various stakeholders to handle TKIB in the transit area.

\section{B. Data Types and Collection Techniques}

A socio-legal research method requires the use of primary data which is collected through observations, interviews, questionnaires or focus group discussions. ${ }^{18}$ The primary data in this research was collected through in-depth interviews at a number of institutions as follows: ${ }^{19}$

a. Shelter on Jalan Transito Km.8 Tanjung Pinang City.

b. Shelter and Trauma Center in Senggarang, Tanjung Pinang City.

c. National Body for the Placement and Protection of Indonesian Overseas Workers (BNP2TKI).

d. Social and Manpower of Tanjung Pinang Government Office.

e. Manpower and Transmigration Office of Riau Islands Office.

In addition to primary data, secondary data is also required by the socio-legal method to supplement the primary data. The secondary data used by this research is comprised of primary and secondary legal materials. Primary legal materials are the authorized materials consisting of legislation, official records or minutes in the making of legislation. ${ }^{20}$ The primary legal materials used in this research consist of:

a. Law No. 39 of 2004 concerning the Placement and Protection of Indonesian Workers Overseas.

b. Government Regulation No.4 of 2013 regarding the Methods of the Placement of Indonesian Overseas Workers by the Government.

c. Government Regulation No.3 of 2013 on the Protection of Indonesian Overseas Workers .

Faculty of Law Universities Indonesia, Depok, 2005).

15 Syahruddin Nawi, Penelitian Hukum Normatif versus Penelitian Hukum Empiris (Makassar: Umitoha Ukhuwah Grafika, 2014), pp.7-10.

${ }_{16}$ Soetandya Wignyosoebroto, Metodologi Penelitian Hukum, Diktat (Kumpulan Tulisan) (Surabaya: Program Pascasarjana UNAIR, Surabaya, 1993).

${ }_{17}$ Amiruddin, loc.cit.

18 Ibid.

${ }^{19}$ The interviews were conducted by Suharyanto under the supervision of Rina Shahriyani Shahrullah. The results of interviews were used by Suharyanto as data for his Master Degree Thesis at Postgraduate Study of Law, Universities Internasional Batam, Indonesia.

${ }^{20}$ Peter Mahmud Marzuki, Penelitian Hukum (Jakarta: Kencana, 2005), p. 141. 
d. Regulation of Manpower and Transmigration Ministry No. PER.14/MEN/X/2010 on the Implementation of the Placement and Protection of Indonesian Overseas Workers.

e. Presidential Instruction No. 6 of 2006 (INPRES 2006) on Policy Reform on Placement and Protection System of Indonesian Overseas Workers.

f. Presidential Regulation No. 81 of 2006 on the Establishment of National Body for the Placement and Protection of Indonesian Overseas Workers (BNP2TKI).

g. Presidential Decree of Indonesia No.106 of 2004 on the Establishment of Coordinating Team for Returning Indonesian Troubled Overseas Workers (TKIB) and their families from Malaysia which was replaced by Presidential Regulation No.45 of 2013 regarding the Coordination of Returning Indonesian Workers.

Secondary legal material explains the existing primary legal materials which consist of: explanations of legislation; books, journals and research reports relevant to Indonesian overseas workers.

\section{Data Analysis Methods}

All data collected in this research were analyzed based on its content (a content analysis) by using the qualitative approach. Qualitative research is especially effective in obtaining culturally specific information about the values, opinions, behaviors, and social context of particular populations, i.e. Tanjung Pinang City. ${ }^{21}$

\section{Research Findings}

\section{A. Research Results}

There are two types of Indonesian overseas workers. Those who go overseas for work with complete documents and through proper channels (via legal employment agencies) are categorized as "legal workers". Those without complete documents and go overseas through improper channels fall within the category of "illegal workers"; thereby they are automatically referred to as "Troubled Indonesian Overseas Workers (TKIB)". Yet, the status of "legal workers" may change to be "illegal workers (TKIB)" because Indonesian overseas workers run away from their employers without having their passports. In many cases, overseas employers whose names are stated in the working contract have paid some amount of the workers expenses. The wages of workers will be deducted to pay back the employers' expenses. In order to guarantee that the workers will fulfill their obligations and will not run away, the employers will detain the workers' passports. When the workers run away or move to other employers, without possessing passports, they can be deported and categorized as "TKIB".

${ }^{21}$ "What is qualitative research?", http://www.fhi.org/nr/rdonlyres/etl7vogszehu5s4stpzb3tyqlpp7rojv4waq37elpbyei3tgmc4ty6dunbccfzxtaj2rvbaubzmz4f/overview1.pdf. 
Based on the interviews, it was revealed that Indonesian overseas workers run away from their employers because of the following reasons:

Table 4: Reasons to Run Away from Employers

(Interviews of TKIB in Tanjung Pinang City)

\begin{tabular}{|c|c|c|}
\hline No. & Type of Cases & Respondents' Statements \\
\hline 1 & Unpaid salary & $\begin{array}{l}\text { My employer did not pay my salary for almost } 11 \text { months, so I } \\
\text { returned to Indonesia (Maftiyah Marsihat, Aminah Salleh, Mia } \\
\text { Bakon, Tumini). }\end{array}$ \\
\hline 2 & Over workload & $\begin{array}{l}\text { I worked as a domestic helper. When I was in Indonesia, my } \\
\text { agent said that I only cleaned one house. When I arrived in } \\
\text { Malaysia, my employer forced me to clean } 2 \text { houses. I was } \\
\text { not able to do it, so I quitted my job and looked for a new job } \\
\text { (Manisa Binti Bukari). }\end{array}$ \\
\hline 3 & Uncomfortable & $\begin{array}{l}\text { My friend got a higher salary than mine although our type of } \\
\text { work was similar. I moved to my friend's employer's house } \\
\text { without telling my employer (Kornelia). }\end{array}$ \\
\hline 4 & $\begin{array}{c}\text { Sexual } \\
\text { harassment }\end{array}$ & $\begin{array}{l}\text { My employer was a bad person. He wanted to rape me several } \\
\text { times, but I succeeded to run away. I was arrested and deported } \\
\text { to Indonesia (Dina). }\end{array}$ \\
\hline 5 & $\begin{array}{l}\text { Abuse/physical } \\
\text { violence }\end{array}$ & $\begin{array}{l}\text { I was always tortured by my employers whenever I made } \\
\text { mistakes even though they were just small mistakes. I was } \\
\text { beaten and no food was given to me (Yumna). }\end{array}$ \\
\hline 6 & $\begin{array}{c}\text { Unsuitable } \\
\text { working hours }\end{array}$ & $\begin{array}{l}\text { I worked at my employer's house without resting. My employer } \\
\text { frequently woke me up at } 2 \text { am to work (Somaene). } \\
\text { I worked from morning to evening almost without stopping. I } \\
\text { only stopped for about } 15 \text { or } 20 \text { minutes for lunch or dinner } \\
\text { (Talina). }\end{array}$ \\
\hline
\end{tabular}

Source: Interviews by Suharyanto.

Some of respondents realized that they were TKIB from the beginning because of:

a. The expiry of visa. Many Indonesian overseas workers are willing to work longer in Malaysia. Respondents interviewed for this research said that the process of obtaining working visa is lengthy. Hence, they stayed in Malaysia and tried their luck even if their visas were expired.

b. Entering Malaysia with a social visit visa. They got arrested by Malaysian Police (RELA), tried by the Malaysia court, put in a prison and deported to Indonesia. 
The number of TKIB in Tanjung Pinang City fluctuates every year as it is shown by the table below

Table 5: Troubled Indonesian Overseas Workers in Tanjung Pinang City (Deported from Malaysia 2005- July 2014)

\begin{tabular}{rr}
\hline Year & Total Number \\
\hline 2005 & 10.752 \\
\hline 2006 & 23.845 \\
\hline 2007 & 34.793 \\
\hline 2008 & 35.114 \\
\hline 2009 & 33.032 \\
\hline 2010 & 22.171 \\
\hline 2011 & 15.799 \\
\hline 2012 & 7.843 \\
\hline 2013 & 19.634 \\
\hline 2014 & 14.402 ( up to July 2014) \\
\hline
\end{tabular}

Source: Social \& Manpower Office of Tanjung Pinang.

Based on the observations at the shelters and Trauma Center in Tanjung Pinang, the process of handling TKIB as follows:

a. TKIB arrive in Tanjung Pinang from Malaysia on Wednesday or Thursday every week.

b. TKIB wait at the shelters between 7-10 days because PELNI (ship) which takes them to Jakarta arrives in Sri Bintan Pura Port of Tanjung Pinang only on Monday or Tuesday.

c. At the Tanjung Priok Port, Jakarta, TKIB is taken care by TKIB task force of Jakarta.

d. The Jakarta task force arranges the returns of TKIB to their home towns. All expenses are burdened by the Central Government under the National Budget (APBN).

Although the government of Tanjung Pinang City has implemented the Presidential Decree of Indonesia No.106 of 2004 on the Establishment of Coordinating Team for Returning Indonesian Troubled Overseas Workers (TKIB) and their families from Malaysia which was replaced by Presidential Regulation No.45 of 2013 regarding the Coordination of Returning Indonesian Workers by providing shelters, the measures and processes of handling TKIB are still inadequate. The interview results below reveal a number of hardships faced by TKIB as well as the stakeholders dealing with TKIB. 
Table 6: Non Legal Problems of TKIB in the Transit Area

(Shelters of Tanjung Pinang City)

\begin{tabular}{clll}
\hline No. & Problem & \multicolumn{1}{c}{ Descriptions } & \multicolumn{1}{c}{ Remarks } \\
\hline 1 & $\begin{array}{l}\text { Budget } \\
\text { constraint } \\
\text { No special budget } \\
\text { for unexpected } \\
\text { circumstances (e.g. } \\
\text { giving birth or death } \\
\text { of TKIB) }\end{array}$ & $\begin{array}{l}\text { All unexpected expenses are burdened } \\
\text { by officers dealing with TKIB. It is } \\
\text { suggested that the Tanjung Pinang Regional } \\
\text { Budget (APBD) allocates funds for TKIB } \\
\text { unexpected expenses. However, the House of } \\
\text { Representatives refuse to allocate budgets } \\
\text { for unexpected expenses on the ground } \\
\text { that TKIB expenses are under the national } \\
\text { budget. }\end{array}$ \\
\hline 2 & $\begin{array}{l}\text { Lack of } \\
\text { facilities }\end{array}$ & $\begin{array}{l}\text { No beds for male } \\
\text { shelter, dirty toilet, } \\
\text { lack of water supply. }\end{array}$ & $\begin{array}{l}\text { No } \\
\text { beneficial } \\
\text { activities at } \\
\text { shelters }\end{array}$ \\
\hline
\end{tabular}

Source: Data analyzed based on the interviews by Suharyanto.

Most of TKIB expressed that their salary was not paid prior to the deportation to Indonesia. They questioned if officers of Social and Manpower Office of Tanjung Pinang City who are in charge of handling TKIB could assist them. The respondent from Social and Manpower Office of Tanjung Pinang City stated that:

We do not have authority to assist TKIB who encountered problems relating to their unpaid salaries in Malaysia. We used to consult the problems to Police Officers, but according to them, it was impossible to resolve the problems because there were no strong evidences that such problems occurred. In addition, TKIB could not become key witnesses because they were only in transit in Tanjung Pinang City.

\section{B. Proposed Model}

Based on the initial research findings above, it is clear that stakeholders in Tanjung Pinang City face a number of hardships and challenges in handling the problems of TKIB. Hence, solutions are needed to tackle the problems, particularly up to now there is no special regional regulation established to deal with TKIB in the transit area.

Prior to this existing research, a number of models were designed:

1. Sharing Model

A 'sharing model' was designed to collaborate all stakeholders at local, regional and international level. Although this model is meant for human trafficking issues rather than TKIB. Yet, this model can be adapted for TKIB because this model engages all stakeholders in the transit area, namely the government agencies, law enforcers, NGOs, academicians, and communities to work together and share their roles, responsibilities, resources, services, information and knowledge in 
providing a comprehensive protection measure. ${ }^{22}$ This model may be considered as a comprehensive model in the sense that all relevant stakeholders engage in the collaboration. However, the pertinent weakness of the model is that it is not equipped with a mechanism of evaluating the performances of the stakeholders. Consequently, the successful performances of stakeholders cannot be measured.

\section{Figure 1: Sharing Model}

\section{Global Challenges}

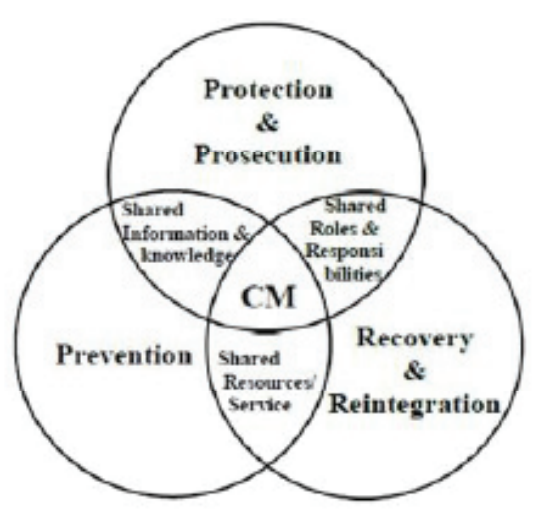

Cooperative Measure (CM) :

Internal Collaboration and International Collaboration

Since the problems of TKIB consist of social and legal problems, the previous models were designed to tackle both problems.

2. Collaborative Model on Legal Service

Collaborative Model on Legal Service combine all expretise of stakeholders, higher education institutions, academicians and legal practitioners.

${ }^{22}$ Rina Shahriyani Shahrullah (2). "Seeking Justice for Trafficking Victims in the Transit Area: Far and Away (A Socio-legal Research in Batam City, Indonesia)," Sophia Law Review Volume 54 No.1 (2010): 85102. 
Figure 2: Collaborative Model on Legal Service

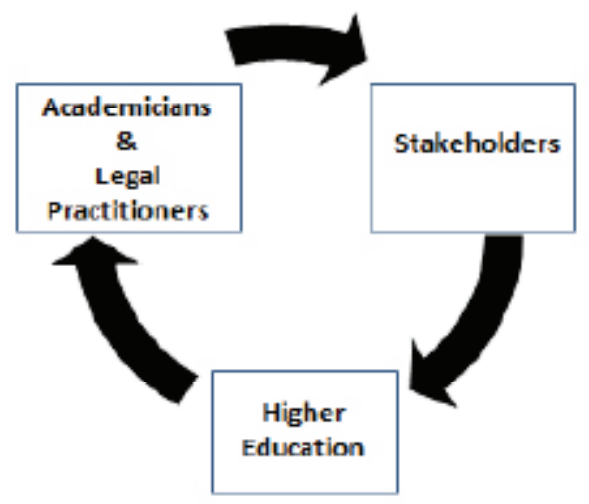

In the Collaborative Model on Legal Service, stakeholders in charge of TKIB provides information and inputs on how to handling TIKB. Based on the inputs of stakeholders, higher education instututions (Perguruan Tinggi) conduct research relevant to TKIB issues. The results of research can be used by academicians (Akademisi) in giving legal opinions and/or expert judgements. Legal opinions and/or expert judgements can be adopted by legal pratitioners (Praktisi Hukum) in assisting TKIB to resolve their legal problems. Expertise of academicians and legal pratitioners can be adopted by relevant stakeholders to establish policies aiming at advocating TKIB in the transit area. ${ }^{23}$ This model may be best to respond to the needs of TKIB's legal assistance. Yet, the model does not clearly describe whether the said legal assistance is pro bono for TKIB. The other flaw of the model is that it merely focuses on the legal service. In fact, TKIB have various problems including financial and psychological ones.

3. Collaborative Fundraising Model

Figure 3: Collaborative Fundraising Model

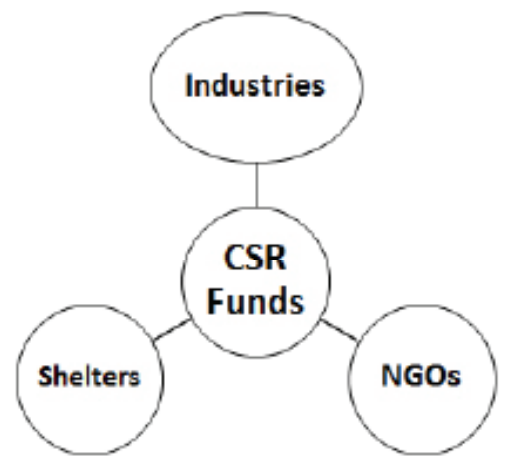

${ }^{23}$ Shahrullah, Rina Shahriyani. Penanganan Buruh Migran Indonesia Pada Daerah Transit (Studi Kasus Dan Lapangan Di Kota Batam, Jakarta: LIPI Press, 2010. 
It was designed from the idea of utilizing Corporate Social Responsibility (CSR) of industries (Industri). CSR funds (Dana CSR) are shared to support the goverment and NGOs (LSM) shelters to improve their services and facilities in handling TKIB. ${ }^{24}$

The Collaborative Fundraising Model was designed to respond to the limitation of the Collaborative Model on Legal Service with regard to financial issues and supports. The very weakness of the model is that there is no monitoring mechanism to ensure the sustainability of CSR provided by industries.

It is clear that the models above are designed only to tackle specific problems, therefore an integrated model should be designed to tackle various problems of TKIB in the transit area.

\section{The integrative-progressive model}

In order to design an integrative-progressive model, the proposed model should adopt the approaches of the three legal theories, namely "Responsive Legal Theory by Nonet-Selznick ", "Progressive Legal Theory by Satjipto Rahardjo" and "Integrative Legal Theory by Romli Atmasasmita ". By virtue of the three legal theories, the proposed model should meet the following requirements:

a) The model should respond social needs and public aspiration.

b) The ultimate purpose of the model is the welfare and happiness of human (TKIB and all relevant stakeholders).

c) The Model should be based on basic values and norms of Indonesian society which is integrated in the State Ideology (Pancasila).

Several steps should be adopted prior to designing an integrative-progressive model. The steps are:

a) Step 1: All relevant stakeholders appeared under the Collaborative Model on Legal Service and Collaborative Fundraising Model should be integrated. The figure below shows the integrated stakeholders which should engage in handling the problems of TKIB in the transit area.

Figure 4: Stakeholders in the Transit Area

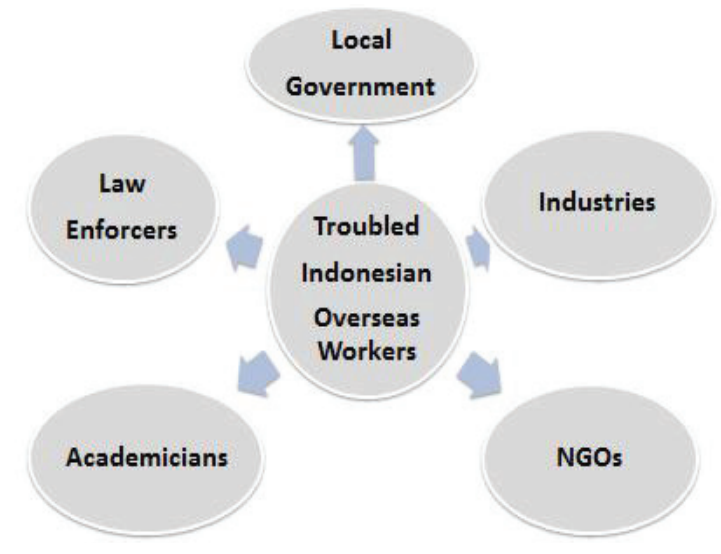

24 Ibid. 
b) Step 2: All stakeholders should perform their functions respectively to ensure that the effectiveness of the implementation of integrative-progressive model in handling TKIB in the transit area. The proposed functions of stakeholders to support the implementation of the model can be described as follows:

Table 7: Functions of Stakeholders in the Transit Area

\begin{tabular}{|c|c|c|}
\hline No. & Stakeholders & Non Exhaustive Proposed Functions \\
\hline 1. & $\begin{array}{l}\text { Local } \\
\text { Government } \\
\text { (TKIB Leading } \\
\text { Sector) }\end{array}$ & $\begin{array}{ll}- & \text { Providing and managing task forces in charge of TKIB. } \\
\text { - } & \text { Coordinating with local government of TKIB. } \\
- & \text { Provide facilities at shelters. } \\
- & \text { Supervising the process of returning TKIB. } \\
\text { - } & \text { Monitoring and evaluating the performance of task } \\
& \text { forces in charge of TKIB. }\end{array}$ \\
\hline 2. & Law Enforcers & $\begin{array}{l}\text { - } \quad \text { Ensuring the process of returning TKIB run smoothly. } \\
\text { - } \quad \text { Monitoring the acts of TKIB at shelters to ensure no } \\
\text { crimes occur. } \\
\text { - } \quad \text { As legal consultants for TKIB. }\end{array}$ \\
\hline 3. & Academicians & $\begin{array}{l}\text { Conducting research on how to improve the process of } \\
\text { returning TKIB. } \\
\text { Providing opinions and advocating TKIB and other } \\
\text { relevant stakeholders. }\end{array}$ \\
\hline 4. & NGOs & $\begin{array}{l}\text { Partnering with local government in advocating TKIB. } \\
\text { Volunteering at shelters. }\end{array}$ \\
\hline 5. & Industries & $\begin{array}{ll} & \text { Providing job information and required skills through } \\
\text { workshops. } \\
\text { - }\end{array}$ \\
\hline
\end{tabular}

Source: Initial Data Analysis by Authors.

c) Step 3: The proposed functions of all relevant stakeholders are shared by adapting the Sharing Model from the previous research in order to resolve non legal problems of TKIB (i.e. funds, facilities and handling process) and problems involving legal approaches (i.e. demanding employers to pay the unpaid salary). The sharing model is modified to suit the problems of TKIB in the transit area. There are three main components in the model, namely "Legal Process, Facilities and Handling of TKIB". This model requires that information, knowledge, roles, responsibilities, resources and services are shared to strengthen and improve the three main components. The approaches of the three legal theories, namely "Responsive Legal Theory by Nonet-Selznick ", "Progressive Legal Theory by Satjipto Rahardjo" and "Integrative Legal Theory by Romli Atmasasmita " should be used as parameters in sharing information, knowledge, roles, responsibilities, resources and services. Since the sharing model is adapted with modification, the model below is referred to as the "Adaptive Sharing Model". 
Figure 5: Adaptive Sharing Model

\section{Legal \\ Process}

\section{$\begin{array}{ll}\text { Info \& } & \text { Roles \& } \\ \text { Knowledge } & \text { Responsibilities }\end{array}$ \\ Handling TKIB \\ Process Resources \\ Facilities}

d) Step 4: Integrating the functions of all stakeholders and the Adaptive Sharing Model.

Figure 6: The Proposed Integrative-Progressive Model

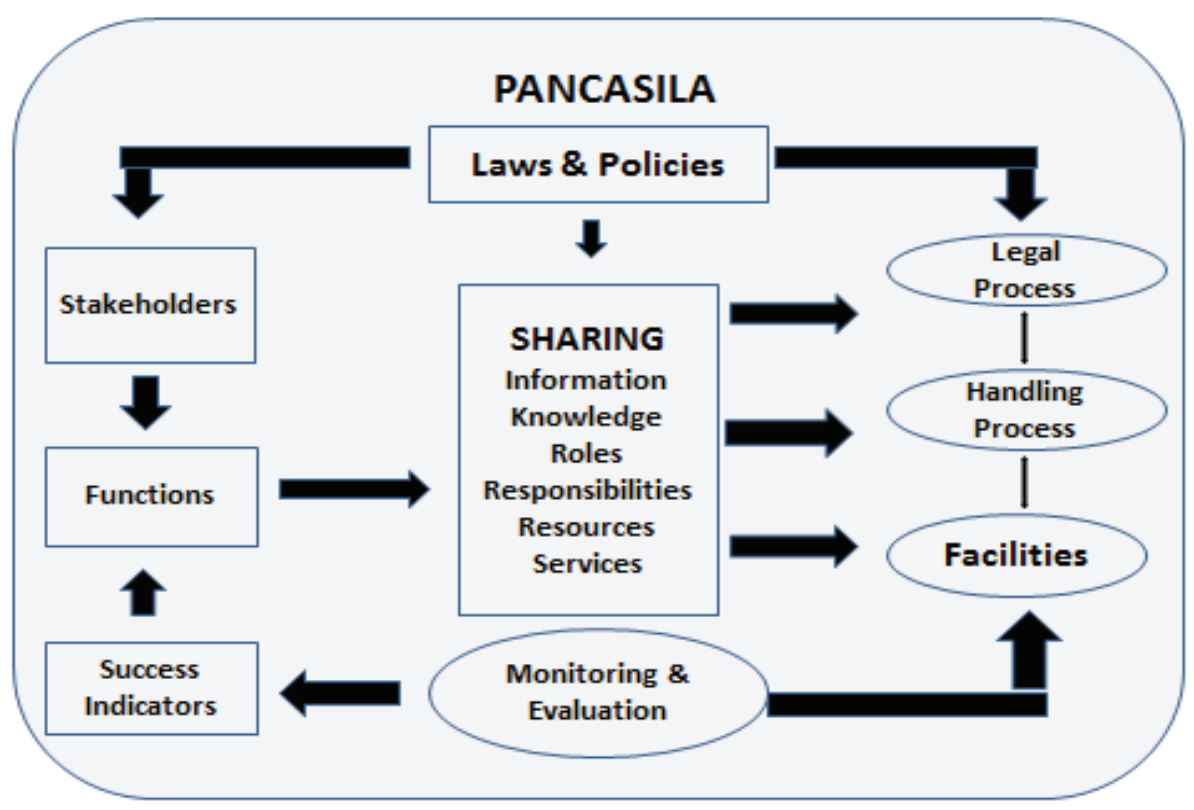


The adoption of the three legal theories in the Integrative-Progressive Model can be explained as follows:

a. The model responds social needs and public aspiration as required by "Responsive Legal Theory by Nonet-Selznick' since the model involves all relevant stakeholders and responds problems and issues relating to TKIB.

b. The model aims to achieve the welfare and happiness of TKIB and all relevant stakeholders as suggested by "Progressive Legal Theory by Satjipto Rahardjo". The progressiveness of the model is reflected by the process of monitoring and evaluation the achievement of success indicators in the performance of stakeholders' functions. Success indicators are not based on stagnant standards. The standards should be continuously improved and increased.

c. The Model is based on the Indonesia State Ideology (Pancasila) as mandated by "Integrative Legal Theory by Romli Atmasasmita ". The five pillars of Pancasila ${ }^{25}$ are manifested in all performances, monitoring and evaluation processes.

d. The Model integrates the previous models for an efficient and effective implementation.

\section{Conclusion}

Most of the Indonesian laws and regulations relating to Indonesian Overseas Workers focus of the placement and protection of workers. The only legal instrument which can be relied by a transit area for TKIB is the Presidential Decree of Indonesia No.106 of 2004 on the Establishment of Coordinating Team for Returning Indonesian Troubled Overseas Workers (TKIB) and their families from Malaysia. Since the Decree is not adequate to tackle all issues and problems faced by TKIB and stakeholders dealing with TKIB in the transit area, a model of collaboration and coordination is needed for all stakeholders to respond the TKIB problems and issues.

An integrative-progressive model is proposed to describe the linkage between all stakeholders. The proposed model adopts the approaches of the three legal theories, namely "Responsive Legal Theory by Nonet-Selznick ", "Progressive Legal Theory by Satjipto Rahardjo" and "Integrative Legal Theory by Romli Atmasasmita" in order to respond social needs and public aspiration. In addition, the proposed model is aimed to improve the welfare and happiness of TKIB and all relevant stakeholders based on basic the Indonesian State Ideology (Pancasila).

The integrative-progressive model is designed by integrating, adapting and modifying previous models (Sharing Model, Collaborative Model on Legal Service, and Collaborative Fundraising Model) on the ground that the previous models have been tested and implemented. Since the Proposed Integrative-Progressive Model is not yet final, the model should be examined by involving more stakeholders. More feedbacks are required to improve the proposed model. FGD can be one of the methods to gain feedbacks.

${ }^{25}$ Pancasila consists of five pillars, namely First Pillar: Belief in One Supreme God, Second Pillar: Just and Civilized Humanity, Third Pillar: The Unity of Indonesia, Fourth Pillar: Democracy Led by People and Wisdom, Fifth Pillar: Social Justice for All Indonesian People. 


\section{Bibliography}

\section{Legal Documents}

Indonesia. Instruksi Presiden mengenai Kebijakan Reformasi Sistem Penempatan dan Perlindungan Tenaga Kerja Indonesia (President Instruction regarding Policy on Indonesian Workers' Placement and Protection System), Peraturan Presiden No. 81 Tahun 2006 (President Instruction No. 81 Year 2006).

Indonesia. Keputusan Presiden tentang Tim Koordinasi Pemulangan Tenaga Kerja Indonesia Bermasalah dan Keluarganya dari Malaysia (Presidential Decree regarding Repatriation of Troubled Indonesian Workers and their Families from Malaysia), Kepres No.106 tahun 2004 (Presidential Decree No. 106 Year 2004).

Indonesia. Peraturan Menteri Tenaga Kerja dan Transmigrasi Republik Indonesia tentang Pelaksanaan Penempatan dan Perlindungan Tenaga Kerja Indonesia di Luar Negeri (Decree of Ministry of Manpower of the Republic of Indonesia regarding Implementation if the Placement and Protection of Indonesian Workers Abroad), Permenaker RI No. PER.14/MEN/X/2010 (Decree of Ministry of Manpower of the Republic of Indonesia No. PER.14/MEN/X/2010).

Indonesia. Peraturan Pemerintah tentang Perlindungan Tenaga Kerja Indonesia di Luar Negeri (Government Regulation on Protection of Indonesian Workers Abroad), PP Nomor. 3 Tahun 2013 (Government Regulation No. 3 Year 2013).

Indonesia. Peraturan Pemerintah tentang Tata Cara Pelaksanaan Penempatan Tenaga Kerja Indonesia di Luar Negeri (Government Regulation regarding Procedure of Placement of Indonesian Workers Abroad), PP. No. 4 Tahun 2013 (Government Regulation No. 4 Year 2013).

Indonesia. Peraturan Presiden tentang Koordinasi Pemulangan Tenaga Kerja Indonesia (Presidential Decree regardings Coordination on Repatriation of Indonesian Workers), Perpres. No.45 Tahun 2013, Presidential Decree No. 45 Year 2013.

Indonesia. Peraturan Presiden tentang Pendirian Badan Nasional untuk Penempatan dan Perlindungan Tenaga Kerja Indonesia di Luar Negeri (Presidential Decree regarding Establishment of the National Agency for the Placement and Protection of Indonesian Workers Abroad), Perpres No. 81 Tahun 2006 (Presidential Decree No. 81 Year 2006).

Indonesia. Undang- Undang Dasar Negara Republik Indonesia Tahun 1945 (1945 Constitution of the Republic of Indonesia).

Indonesia. Undang-Undang tentang Penempatan dan Perlindungan Tenaga Kerja Indonesia di Luar Negeri (Law regarding Placement and Protection of Indonesian Workers Abroad), UU No.39 Tahun 2004, LN No. 133 Tahun 2004 (Law Number 39 year 2004, SG No. 133 Year 2004)

\section{Books}

Amiruddin. Pengantar Metode Penelitian Hukum. Jakarta: Raja Grafindo Press, 2004.

Atmasasmita, Romli. Teori Hukum Integratif (Rekonstruksi Terhadap Teori Hukum Pembangunan dan Teori Hukum Progresif). Yogyakarta: Genta Publishing, 2012.

HS, Salim. Perkembangan Teori dalam Ilmu Hukum. Jakarta: Raja Grafindo Persada, 2010.

International Migrant Workers Union (IMWU). Permasalahan Buruh Migran Indonesia Di Negara-Negara Non ASEAN. 2006.

Marzuki, Peter Mahmud. Penelitian Hukum. Jakarta: Kencana, 2005.

Mertokusumo, Sudikno. Teori Hukum. Yogyakarta: Universitas Atma Jaya, 2011. 
Nababan, Benhard. Permasalahan Buruh Migran Selama Tahun 2007. Jakarta: Migrant Care, 2007.

Nawi, Syahruddin. Penelitian Hukum Normatif versus Penelitian Hukum Empiris. Makassar: Umitoha Ukhuwah Grafika, 2014.

Pramodharwardani, Jaleswari. Perlindungan Hukum Terhadap Pengiriman Buruh Migran Perempuan Indonesia Ke Malaysia. Jakarta: LIPI Press, 2007.

Rahardjo, Satjipto. Hukum Progresif Urgensi dan Kritik. Jakarta: Penerbit Kompas, 2006.

Rahardjo, Satjipto. Membedah Hukum Progresif. Jakarta: Penerbit Kompas, 2006.

Saad, M. Hasballah. Panduan Buruh Migran Tenaga Kerja Indonesia/TKI di Taiwan. Jakarta: Komnas HAM, 2005.

Shahrullah, Rina Shahriyani. Penanganan Buruh Migran Indonesia Pada Daerah Transit Studi Kasus Dan Lapangan Di Kota Batam. Jakarta: LIPI Press, 2010.

Tanya, Bernard L. Teori Hukum Strategi Tertib Manusia Lintas Ruang dan Generasi. Yogyakarta: Genta Publishing, 2010.

Wignyosoebroto, Soetandya. Metodologi Penelitian Hukum. Diktat (Kumpulan Tulisan), Surabaya: Program Pascasarjana UNAIR, 1993.

\section{Articles}

Shahrullah, Rina Shahriyani. "Seeking Justice for Trafficking Victims in the Transit Area: Far and Away (A Socio-legal Research in Batam City, Indonesia)." Sophia Law Review Volume 54, No.1 (2010): 85-102.

Shahrullah, Rina Shahriyani. “'The Missing Link' Dalam Perlindungan Tenaga Kerja Indonesia Bermasalah (TKIB) Di Daerah Transit (Studi Lapangan Pada TKIB Di Kota Batam)." Jurnal IPTEKS Terapan Volume 4 No.3 (December 2010): 3.

\section{Websites}

Atmasasmita, Romli. "Mengurai Sepintas Hukum integratif." http://www. negarahukum.com /hukum/mengurai-sepintas- \%E2\%80\%9Chukumintegratif\%E2\%80\%9D-romli-atmasasmita.html. Accessed 3 May 2015.

. "What is qualitative research?" http://www.fhi.org/nr/rdonlyres etl7vogszhu5s4stpzb3tyqlpp7roj v4waq37elpbyei3tgmc4ty6dunb

ccfzxtaj2rvbaubzmz4f/overview1.pdf. Accessed 3 May 2015.

Mahidol Migration Centre, Institute for Population and Social Research, Mahidol University, "Migrant Workers' Right to Social Protection in ASEAN: Case Study of Indonesia, Philippines, Singapore and Thailand (Data from BNP2TKI 1999)." http://www.ilo.org. Accessed 3 May 2015. 